\title{
Discussion on Issues faced by Forestry's Sustainable Development and Its Legal Measures in China
}

\author{
Lujie Duan \\ State Key Laboratory of Mining Disaster Prevention and Control Co-founded by Shandong Province and the Ministry of \\ Science and Technology, Shandong University of Science and Technology, Qingdao 266590, China \\ College of Earth Science and Engineering, Shandong University of Science and Technology, Qingdao 266590, China \\ E-mail: miaomiaofangkun@163.com
}

\begin{abstract}
Forestry is the main body of ecological construction, as well as one basic industry and commonweal career for the sustainable development of economic society. The importance of forest resources and forestry requires us to deepen the conception of sustainable development into various aspects of forestry construction. This article is divided into three sections. In the first section, the definitions of Forestry, Sustainable Development and Sustainable Forestry are respectively described. In the second section, the current situation of China's forestry and the problems related to its sustainable development are presented. The author makes an analysis from following four aspects: 1 . Recoverable resources in the forestry are shrinking and forest resources have been seriously destroyed, deadly threatening the ecological balance; 2: The current forest management is extensive, and the research on forestry technologies lags behind; 3: People are lack of awareness in the sustainable development of forestry, so there is no sufficient public participation in this issue; and, 4: The forestry management is complex and relevant regulations need to be further improved. In the third section, legal measures to achieve the sustainable development of forestry are proposed. The author suggests preparing and improving China's forestry laws with international conventions and agreements as the reference; strengthening the research on basic theories to build a scientific and rational overall theoretical framework; and taking the sustainable development of forestry as the guide to improve various forestry laws and regulations so that the current situation of China's forestry is greatly improved.
\end{abstract}

Keywords-Forestry; Sustainable Development; Forestry Law; Public Participation; Legal Measures

\section{THE UNDERSTANDING TO FORESTRY AND ITS SUSTAINABLE DEVELOPMENT}

So-called forestry is the basic industry and commonweal career organized in order to conduct forest operation to do timber, forest product production and protective resource operation and use the latter as foundation. The forest operation includes forest cut and update, forest protection (including diseases and bugs prevention and fire-fighting), reforestation, forest cultivation and construction and management of city forest and other serious of forest affair activities [1].
Sustainable development means the capabilities not only satisfying the demands of modern people but also not hurting the offspring. There are connections and differences between sustainable development and environment protection. Environment protection is an important aspect of sustainable development. Sustainable development's core is development, but it is required to promote the development of economy and society in the precondition of strictly controlling population, improving population qualification, protecting environment and sustainable use of resources $[2,6]$.

Sustainable forestry is forestry practice activities in the precondition that forestry ecology system guarantees its productivity and update abilities as well as not harming the ecological system and biodiversity, which is the forestry cultivating and using forest to exert its multiple functions through general development and protecting the quality of soil, air and water and the living environment of animals and plants in the forest, not only satisfying the demands of modern economic development, but also not harming its future demand abilities[7].

\section{THE CURRENT DEVELOPMENT SitUATION IN CHINA's FORESTRY AND THE PROBLEMS FACED BY SUSTAINABLE DEVELOPMENT}

The fifth national forest resource check result issued by National Forestry Administration shows that our forest cover rate has increased by $1.43 \%$ and net increase forest area is 1370.3 hectares from 1994 to 1998. As a whole, the current situation of our forest resources makes people with half happiness and half bitterness; there is a long way to go for the construction of forest ecology. The current situation of our forest resources: there is 158.941 hectares forest area, and the forest cover rate is $16.55 \%$; the forest accumulation volume is 11.2 billion cube meters; National artificial area (excluding Taiwan province) is 46.667 million square meters, and the accumulative volume is 1.01 billion cube meters, and the artificial area lists the top of the world. Our forestry has achieved the remarkable results; however, there are many problems existed for realizing the sustainable development of forestry, which mainly includes the following four aspects: 
A. The forest resources to be used shrinks, and the forest resources are damaged seriously and the ecological balance is threatened

In the initial phase of our forestry development, which is just under the period providing accumulation for national industrialization, enormous process of cutting wildwood makes our forestry resources shrank significantly[8].In the second and third phase of our forestry development, although the forestry has been reformed, and determined the forestry ownership responsibility system, however, the forestry management system has not been smoothed yet, sections cut, responsibility and ownership separated and production \& sale disconnected. In addition, the research, promotion and information development of forestry technology lag behind, which makes the makeup technology of forestry resources lag behind, and cutting and updating methods are improper and then make the ecological imbalance in the forestry become more and more obvious [9].

B. The operation and management of the forest is rough, and forestry technology research lag behind

The fourth national forestry census shows: the usage rate of national forest land is only $50.49 \%$, and the average closing level of the forest is 0.29 , and the average living vertical wood area of the forest is $83.7 \mathrm{~m} / \mathrm{hm}$, which is much lower than the world average level. Due to the serious shortage of technology investment of the forest, which makes the technology advance of the forest lag behind seriously, and the technology contribution share only covers about $20 \%$, which is much lower than other industries. There lack of comprehensive information exchange between various forestry institutions, and there are no research strengths integrated, which causes big waste of many resources. There lack of collaboration between colleges and forestry institutions. There is long way to go for the transfer ability of forestry research results, and it needs to transfer the research results into productivity.

\section{People lack of the awareness for the sustainable development of the forestry and there lacks of public involvement in the sustainable development of forestry}

There lacks of public involvement in forestry management and operational activities. As the basic industry in national economy and social commonweal career, the forestry bears the important task for maintaining ecological safety of national land and promoting the sustainable development of the economy, however, there is not public awareness for the sustainable development of the forestry formed in China, during the planning economy period, in the work of forestation, most of them rushed to make differences and did things not according to the natural law of the forestry and economic law: there appeared too dense forest trees, and the polarization of the forest is serous, and the tree category is single, which formed big-scale pure forest, and worsened the diseases and bugs of the forests and made the woods with low survival rate and the economic benefit was poor[10].

\section{The complexity of the forestry management and lack of relevant regulations}

The forest operation is a very complicated process, and the demand to information volume is increasing and the relevant systems and laws are exerting more and more important functions in the development of forestry development, although many scholars have made deep research to forestry law, it can not satisfy the realistic demand of forestry construction and development, there are problems like insufficient research depth, insufficient broadness and low level[11,12-16] It mainly includes, the basic conception definition is not correct, lack of deep analysis to basic theory, the construction of whole framework is not reasonable, the research with ordinance as principle is more, there is little research with legal principle as purpose and even blank and there are more researches on forestry law itself, there are very few researches on the legal relationship between forestry tree and other parts, there are more researches on domestic forestry law and there are little research to foreign forestry law even nothing.

\section{The LEgal MEASURES REALIZING THE SUSTAINABLE DEVELOPMENT OF FORESTRY}

In order to realize the sustainable development of the forestry in China, this paper mainly discusses the legal measures for the sustainable development of the forestry in China, and focus on understanding and explaining the sustainable development of forestry in terms of law and policy and system levels.

\section{A. Borrow international agreement, international pact to guide the establishment and perfection of forestry law in China}

During and after UN Environment Development Conference, there were several legal documents with or without binding power generated, which made certain influence to the operational management and use to forestry. Forest Issue Principle Statement confirmed that nations own the sovereignty using their forest resources to satisfy their own requirements; meanwhile, it stated that additional expenses generated from sustainable development must be borne by international society. Three well-known international pacts signed during and after UN Environment Development Conference: Biodiversity Pact, Climate Change Framework Pact and Anti-deforestation Pact and two "soft law" documents, Rio de Janeiro Declaration and Forest Issue Principle Declaration. Biodiversity Pact specifically passed the reserve regulation determined, and protects forest biological system and breeds. Therefore, it combines some contents of sustainable operation of the forestry. Although the biodiversity based on forestry is not only the content focused, but also many articles in this pact can support the global services provided by the forestry.

There are more than 60 international environment resource agreements and members of WTO in China. The international rules in terms of international forest protection and forest product trading have guiding meaning to the sustainable development and protection of the forest in China. As a member of these international pacts, whose rules are also important components of our 
forestry law system, but forestry law in our country does not internalize the contents of these international documents into the system, which can not realize the connection to the international society. Whereas, in order to realize the sustainable development of the forestry in our country, during the establishment and modification of the forestry in our country, it should borrow the principles from international forestry pact, which can make our laws be capable of really guaranteeing the application of various pacts in our country, and then develop the forestry law with Chinese characteristics.

\section{B. Strengthen the research on basic theory issue, try to construct scientific and reasonable entire theory framework of forestry law}

It is required to apply the existing research result in law to deeply analyze and discuss basic theory issues of forestry law. For example, apply the theory of contract law to analyze the legal nature of risks may exist in agent forestation. Strengthen the research with law theory as principle. It is required to persist on focusing both the research with law articles as principle and the research with law theory as principle to promote the continuous upgrade of research level of forestry law theories. Strengthen the research on the relationship between forestry law and other department laws. It not only researches the relationships between forestry law and other general department laws including industrial law and commercial law, but also researches the relationships between forestry law and civil law, economic law, administrative law, commercial law and other traditional department laws. Strengthen the research on foreign forestry law. Strengthen the translation work on foreign forestry laws and regulations; especially strengthen the introduction and translation of forestry laws from the powers like Canada and Brazil [16-17] etc. To absorb the latest research results of foreign forestry law theories to continuous improve the level of forestry law theories in our country through strengthen the research on comparative law.

\section{Use sustainable development as guidance to complete the specific contents of various forestry laws and regulations}

Sustainable development is not only the sustainability in terms of resource application, but also sustainability in terms of ecological benefits and social benefits. Forest resources include forest, woods and forest land as well as the wild animals, plants and microorganisms depending on forest, woods and forest land, and it is the material basic for the sustainable development of forestry and ecological construction. In order to realize the sustainable development of forest resources, firstly, people should establish the thought of sustainable development, and coordinate the contradiction between economic and social development and forest ecology development to satisfy the modern people and our offspring's demands in terms of society, economy, culture and spirit. The amending of forest laws and regulations should emphasize the conception of sustainable forestry, and strengthen the comprehensive adjustment of sustainable forestry and strengthen the management to forestry.
During completing various specific contents of forestry laws and regulations, take Forest Law for example, the forest category has not adapted to the reality of development of ecological forest, which can categorize the forest into two, including ecological commonweal forest and commercial forest, and adhere to the principle of strict management to ecological commonweal forest and opening and active commercial forest to conduct category operation. According to its mechanism operation, commercial forest emphasizes defining the ownership of forest resources in terms of system design, and constructs complete forest resource use right trading system, meanwhile, complete corresponding system association, for example, construct forest insurance and forestry guaranty system etc. During the commonweal system, because the rights that ecological commonweal forest operators enjoy the forest resources are limited, new Forest Law needs to specify the resource ecology benefit compensation system and implement the compensation to economic benefit, and smooth the distribution relationship between forest resources and ecological benefits in terms of law. During the process of setting rights and obligations, it should change the unreasonable location to administrative hosts and regulate the obligations should be borne by administrative hosts and define its law obligations.

\section{CONCLUSION}

The importance of forest resources and forestry development require us to deepen the conception of sustainable development into various aspects of forestry construction, during the development of forestry, the forestry laws and regulations should embody the basic perspectives of putting people first and sustainable development, and it needs to borrow international pacts and international agreements to guide the establishment and completion of the forestry laws and regulations in our country, and strengthen the research on basic theory issue, and try to construct scientific and reasonable forestry laws and regulations theory entire framework, and use sustainable development as guidance to complete the specific contents of various forestry laws and regulations to realize the sustainable development of the forestry in our country.

\section{REFERENCES}

[1] Guan Baijun, Shi Kunshan. Research on sustainable development of forests [J]. World Forestry Research, 1995, 8 (004): 1-6.

[2] Zhang Yuzhen, Wangfucai. Research survey on sustainable development of forestry $[\mathrm{J}]$. Hebei Forest and Fruit Research, 1999, 14 (001): 7-12.

[3] Guo Zhiwei, Dai Weimin. Status and prospect of research on sustainable development of forestry [J]. World Forestry Research, 2003, 16 (004): 1-6.

[4] Zheng Siwei. On economic sustainability of sustainable development of forestry [J]. Issues of Forestry Economics, 1999 (001): 41-45.

[5] Zhang Jianguo. Forest management and sustainable development of forestry [J]. F Issues of Forestry Economics, 2002, 22 (003): 131-133.

[6] Huang Xuanrui, Teng Qihe. Basic understanding of issues of sustainable forestry development in China [J]. Forestry Science, 2000,36(004):85-91. 
[7] Shen Guofang.Sustainable development of forestry of China and its key scientific issues [J]. Advances in Earth Science, 2000, 15 (001) $10-18$.

[8] Tangjun. Sustainable development of forestry [J]. Sichuan Forestry Exploration and Design, 1997 (003): 13-18.

[9] Hou Yuanzhao. Framing theory on sustainable development of forestry and sustainable forest management (Second half) $[\mathrm{J}]$. World Forestry Research, 2003, 16 (002): 1-6.

[10] Zhang Zhiping. On the improvement of forestry law and sustainable development [J]. Journal of Nanjing Forestry University: Humanities and Social Sciences, 2001, 1 (004): 34-37.

[11] Gan Ruixin, Wang Fengyou. Survey on index system and comprehensive evaluation of sustainable development of forestry [J]. Protection Forest Science and Technology, 2005 (004): 38-40.
[12] Huang Xuanrui, Gao Yu'e. Environment, goal and means of sustainable development of forestry [J]. Hebei Forest and Fruit Research, 1998, 13 (003): 251-256.

[13] Zhou Xunfang. Historic change of forestry and amendments on "Forestry law" [J]. Modern Law, 2004, 26 (005): 70-73.

[14] Wu Fuzhao, Cao Kangtai. Interpretation of forestry law of the People's Republic of China [Z] [J]. 1998.

[15] State Council Regulations for the implementation of forestry Law of the People's Republic of China [J]. 2000.

[16] Zhang Lei, Characteristics and several law enforcement related issues of forestry law and regulations for the implementation of Forestry Law [J]. Forestry Economics, 2001.

[17] Zhang Lei. Forestry Law [J]. Forestry Economics, 2001 (006): 1016. 